\title{
Changing of University Teaching Management under the Background of the Transformation of Local Undergraduate Colleges and Universities
}

\author{
Feng GAO ${ }^{1, a}$, Qinghong QU ${ }^{2, b}$, Shu LIU $3, \mathrm{c}$ \\ ${ }^{1}$ College of Physics and Electronic Information, Baicheng Normal University, Baicheng \\ 137000,China \\ ${ }^{2}$ Media College, Baicheng Normal University, Baicheng 137000,China \\ ${ }^{3}$ College of Mechanical Engineering, Baicheng Normal University, Baicheng 137000,China \\ aemail:gaof317@163.com; bemail:quqinghong@163.com; 'email:dimnet@163.com
}

Keywords: transformation; local undergraduate colleges and universities; teaching management

\begin{abstract}
In recent years, at least six hundred undergraduate colleges and universities in China, which almost half of total, will transfer to the technical applied undergraduate universities or vocational education universities. Under the background of transformation, a part of undergraduate colleges and universities will face the adjustment of training skills. Because our country has always laid emphasis on academic and neglected skill training in the last years, which lead to many students continue to study for a master or doctor degree after bachelor degree. Although the academic research is very important, the actual operation ability is more important, so the country need balance distribution and development of those two skills, meanwhile also encourage local colleges and Universities to transfer the teaching management for the needs of their own transformation.
\end{abstract}

\section{Introduction}

With the current China's higher education reform, more and more universities, especially local colleges and universities begin to transition for ensuring the further development of the school. It is a natural disadvantage of local colleges and universities that the school-running history is short, the school-running experience is insufficient and the school-running mode is not rich. How to steadily promote the development of the colleges and universities in the tide of economic development, improve the quality of teaching, and improve the students' employment rate of local colleges and universities is a difficult problem to be solved as soon as possible. Depending on national policy guidance for local colleges and universities transformation, it is the only path of local colleges and universities to seek development that transferring to technical applied undergraduate universities and improving the quality of running -school. Teaching management is the guarantee of teaching quality, how to change the teaching management to adapt to the transformation school development is the key to the success of the transition of the colleges and universities. So, it has become an essential problem that how to effectively change teaching management in local colleges and Universities under the background of transformation. Some studies have been done in this paper about change teaching management in order to provide useful reference for the people concerned.

\section{Problems of Teaching Management in Local Colleges and Universities}

Only pay attention to theoretical knowledge, neglect skills training. With the development of economy and improvement of people culture consciousness, the enrollment rate is getting higher and higher. But as China's population gradually increase, there is increasing pressure for employment which makes many college students are face with the serious unemployment problem after graduation. The main reason of those problems is that many local colleges and universities only pay attention to explain the theory of knowledge and do not realize the importance of skills training in the process of teaching. In this way students just memorize mechanically some theoretical knowledge, and can't be competent enterprises assigned tasks. Due to the lack of 
appropriate skills training in school in real practice which resulting their unemployment. In addition, some local undergraduate colleges and universities only regard student achievement as the only standard to evaluate students, whether scholarship or selection of excellent and advanced students, points are primary gist, thus students will mostly focus on theoretical knowledge learning for getting a scholarship or obtaining the outstanding title, that is not only harmful to the development of colleges and universities but also not good for the cultivation of society talents.

Local colleges and universities management loose, students lack of autonomous learning ability. Students work hard for realizing their dreams and entering a good university in the period of high middle school, but after going to colleges, they think that their task has been completed and only need to complete the class hours and corresponding credit needs at the university stage which are required by the colleges. After leaving their parents some students are poor self-control and can not consciously complete the daily learning content, long-term later students will continue to develop the habit of lazy psychological and lost the power to fight. In addition, local undergraduate colleges and universities management itself is loose, student's learning relatively free the pressure small, the school also rarely organizational learning and other major activities, which make students are lack the necessary constraints and are very few independent learning, so after graduation they are not proficiency in a particular line to meet the demand of the society.

The way of teaching falls behind. With the development of economy, the network media has penetrated into all aspects of life, the connecting between the mobile phone, computer, multimedia and human life is more and more closely, teaching is no longer a traditional single mode of teaching and learning, but also under the background of new media interactive communication between teachers and students through the computer or mobile phone media terminal, and achieve extensive information and traffic by interacting sing WeChat. QQ, micro-blog and other communication software. But all the time due to the deep influence of traditional media, some colleges and universities are still in the habit of using the blackboard and books and other traditional media teaching, thus are not conducive to stimulate students' interest in learning the theoretical knowledge, and not conducive to help students better understand the abstract. In addition, for in the teaching process the lack of communication with students using computer and mobile phone and other new media, teachers cannot timely master the learning situation of students, students cannot timely fed back problems met in learning, thus affecting the teaching effect.

\section{Transformation Scheme of Teaching Management in Local Colleges and Universities}

Pay more attention to technical skills training. In the process of transformation of the local colleges and universities, colleges and universities should adapt to the ideas of school development and develop a management plan fit for the development of colleges and universities in accordance with the school size, teaching objectives, teaching level. In the process of development of the local colleges and universities, if colleges and universities cannot change the teaching management concept, which will not only affect to the students' level of seniority, but also reduce the college education quality. So before transforming of the local colleges and universities, the most important thing is to clarify the transformation goals, educational goals and make clear the cultivation of academic talent or technical talents. Because the teaching of colleges and universities, always pay more attention to the research of the theory and ignore the machine operation in the practical skills training, so in the teaching process of the major local colleges and universities, the learning focus should be changed from the traditional theory-study to operation skill research which means students in school will learn hands-on ability and no longer completely read and memorize a textbook. In this regard, the local colleges and universities firstly should increase investment on teaching equipments and set more hands-on courses and scientific experiment courses for cultivating practical ability of students. Secondly, teaching concepts of teachers should be changed and let the teacher realize the importance of hands-on operation ability, and in the teaching process teachers should achieve the principle of combining theory with practice to improve teaching quality and let the students find a good job after graduation. 
Strengthen the training, improve students' ability of independent innovation. All the time a lot of students in the local colleges and universities are lack of independent innovation capability, do not like to think independently and not love researching questions, they are accustomed to search for answers from the books or online and are lack of innovation awareness when encountering problems. This way does not conform to modern social requirements for college students, but also can not meet the needs of enterprises for talents faced with this situation. Facing with students' independent innovation ability lower, the local colleges and universities create a good innovation environment for the students and encourage and support students to innovate. Besides, teachers should regard the students as the main body of learning and let students actively involved in classroom teaching and encourage them to actively explore, by this way make the students think much and independent innovation so as to improve their independent innovation ability to adapt to the social demand for talent.

Application of new media for teaching. Communication mode of the traditional media teaching is no longer the mainstream of modern society, teaching mode combining new media and traditional media slowly enter into the stage. In the new media network era, because new media more convenient compared to traditional media, people pay more attention to communicate using the new media. New media such as mobile phones which can spread of a wide range of information and include audio and video in one to meet the public's desire for knowledge and curiosity of all kinds of information. Therefore, in the teaching process teachers must introduce the new media technology into the classroom and reasonably use multimedia in teaching, and can strengthen the communication with students through some communication platform on the mobile phone, timely to grasp the students' learning dynamics so as to improve their teaching methods. In addition, In order to improve the students' ability, teachers should also use the new media technology and take the way of distance learning to improve the students' skills.

\section{Summary}

Under the background of local Colleges and universities transformation, the transformation of the universities teaching management is a complicated work, colleges and universities should make in a clear understanding of the school size, teaching objectives and teaching level of foundation, and then clear objectives and direction of universities transformation. Local Colleges and universities should changes in curriculum setting to improve technical skills training, and pay attention to improve the students hands-on practice and the ability of independent innovation, and change the teaching idea, using new media teaching, improve the quality of teaching, and encourage teachers to pursue further study, promote technology teachers number. Teaching management is the key to the quality of university running, only as soon as possible to change the teaching management to adapt to the new situation of transformation and development, local colleges and universities can achieve with further development

\section{References}

[1] Sifei Xia, Donghong Liu, Lin Yu, etc. Enhance building of teaching quality management system of colleges and universities, J. Heilongjiang Researches on Higher Education, 3 (2004)82-84.

[2] Changzhi Yu. Thoughts on strengthening and innovating the management of colleges and universities in the new period, J. Journal of Anhui Institute of Metallurgical Science and technology, 15(2013).

[3]Wu Ping. Building Modern Vocational Education System and Accelerating Modern Vocational Education Development, J, Liaoning Higher Vocational Technical InstituteJournal.6(2015)3-6. 